\title{
Pengaruh Waktu Pre Freezing terhadap Kualitas Semen Beku Sapi Bali di UPTD IB Bengkulu
}

\author{
Nur Jamiah Rangkuti ${ }^{1 *}$, Tatik Suteky ${ }^{1}$, Heri Dwi Putranto ${ }^{1}$ \\ ${ }^{1}$ Jurusan Peternakan, Fakultas Pertanian, Universitas Bengkulu \\ *Corresponding author: nurjamiahrangkuti27@gmail.com
}

\begin{abstract}
Abstrak
Sapi Bali merupakan salah satu aset nasional yang cukup potensial untuk dikembangkan melalui inseminasi buatan (IB). Pada dasarnya kualitas semen cepat menurun dengan adanya bahan pengencer ataupun tanpa bahan pengencer. Untuk meminimalisir penurunan kualitas semen cair, maka diperlukan bahan pengencer yang mengandung komposisi yang sesuai dengan perbandingan yang tepat antara pengencer dengan semen. Selain pengencer, waktu Pre freezing juga mempengaruhi kualitas semen yang dibekukan. Penelitian ini bertujuan untuk mengevaluasi pengaruh waktu pre freezing terhadap kualitas semen beku sapi Bali di UPTD IB Bengkulu dengan parameter yang diamati motilitas, persentase hidup, dan abnormalitas spermatozoa. Penelitian ini menggunakan satu ekor sapi Bali berumur 5 tahun. Rancangan Acak Lengkap dengan 4 perlakuan dan 18 kali ulangan. Perlakuan T1= Pre freezing selama 5 menit, T2= Pre freezing selama 7 menit, T3= Pre freezing selama 9 menit, dan T4= Pre freezing selama 11 menit. Data yang diperoleh dianalisis menggunakan sidik ragam (ANOVA), apabila hasil analisis berpengaruh nyata $(\mathrm{P}<0,05)$ maka dilanjutkan dengan uji Duncan's Multiple Range Test (DMRT). Hasil penelitian menunjukkan bahwa perlakuan berpengaruh tidak nyata terhadap motilitas spermatozoa, persentase hidup, dan abnormalitas spermatozoa $(\mathrm{P}>0,05)$. Pemeriksaan semen segar secara makroskopis dan mikroskopis layak untuk diproses menjadi semen beku. Meskipun tidak adanya pengaruh yang nyata terhadap semua parameter yang diamati, motilitas tertinggi diperoleh pada perlakuan T4 (waktu pre freezing selama 11 menit), persentase hidup tertinggi diperoleh pada perlakuan T3 (waktu pre freezing selama 9 menit), dan abnormalitas yang rendah terdapat pada perlakuan T3 (waktu pre freezing selama 9 menit). Kesimpulan dari penelitian ini bahwa waktu pre freezing yang berbeda (5, 7, 9, dan 11 menit) tidak mempengaruhi motilitas, persentase hidup, dan abnormalitas spermatozoa.
\end{abstract}

Kata kunci: Kualitas semen beku, Pengencer, Sapi bali, Waktu pre freezing

\section{Abstract}

Bali cattle are one of the national assets with potential to be developed through artificial insemination (IB). Basically, the quality of cement decreases rapidly in the presence of diluents or without diluents. To minimize the decrease in the quality of liquid cement, it is necessary to use a diluent containing an appropriate composition with the right ratio of diluent to cement. In addition to diluent, pre freezing time also affects the quality of frozen semen. This study aimed to evaluate the effect of pre freezing time on the quality of frozen semen of Bali cattle at UPTD IB Bengkulu with the parameters observed were motility, survival percentage, and spermatozoa abnormalities. This study used one 5 year old Bali cattle. Completely Randomized Design with 4 treatments and 18 replications. Treatment $T 1=$ Pre freezing for 5 minutes, $T 2=$ Pre freezing for 7 minutes, T3= Pre freezing for 9 minutes, and T4= Pre freezing for 11 minutes. The data obtained were analyzed using variance (ANOVA), if the results of the analysis had a significant effect $(P<0.05)$, then continued with Duncan's Multiple Range Test (DMRT). The results showed that the treatment had no significant effect on spermatozoa motility, survival percentage, and spermatozoa abnormalities $(P>0.05)$. Macroscopic and microscopic examination of fresh semen is feasible to be processed into 
Prosiding Seminar Nasional Pembangunan dan Pendidikan Vokasi Pertanian

Politeknik Pembangunan Pertanian Manokwari, 31 Juli 2021

e ISSN : 2774-1982

DOI : https://doi.org/10.47687/snppvp.v2i1.183

frozen semen. Although there was no significant effect on all parameters observed, the highest motility was obtained in the T4 treatment (11 min pre freezing time), the highest survival percentage was obtained in the T3 treatment ( 9 min pre freezing time), and the lowest abnormality was found in the T3 treatment. T3 (9 min pre freezing time). The conclusion of this study was that different pre freezing times (5, 7, 9, and 11 minutes) did not affect the motility, survival percentage, and abnormalities of spermatozoa.

Keywords: Bali cattle, Diluent, Frozen semen quality, Pre freezing time

\section{PENDAHULUAN}

Sapi Bali merupakan salah satu aset nasional yang cukup potensial untuk dikembangkan agar terpenuhi kebutuhan daging nasional. Breed sapi Bali telah meluas dan menyebar hampir ke seluruh wilayah Indonesia, didukung karena keunggulan karakteristik yang dimilikinya berupa tingkat kesuburan yang tinggi, persentase beranak sampai $80 \%$, daya adaptasi lingkungan yang baik, sapi pekerja yang efisien, dan dapat memanfaatkan hijauan dengan kualitas gizi rendah, sehingga lebih diminati oleh petani peternak untuk dipelihara (Ngadiyono, 1997).

Inseminasi Buatan (IB) merupakan salah satu teknologi reproduksi yang bisa digunakan untuk menambah populasi sapi Bali menggunakan semen beku yang berasal dari pejantan unggul sapi Bali. Penggunaan semen beku banyak memberikan manfaat, di antaranya dapat mengoptimalisasi fungsi pejantan, menghemat biaya pemeliharaan ternak jantan, dan semen beku lebih tahan lama karena bisa dipakai setelah beberapa tahun kemudian.

Pada dasarnya kualitas semen cepat menurun dengan adanya bahan pengencer ataupun tanpa bahan pengencer. Untuk meminimalisir penurunan kualitas semen cair, maka diperlukan bahan pengencer yang mengandung suatu medium yang sesuai dengan perbandingan yang tepat antara pengencer dengan semen. AndroMed ${ }^{\circledR}$ merupakan pengencer untuk semen segar yang mengandung protein, karbohidrat, mineral (natrium, kalsium, kalium, magnesium, klorida, fosfor, dan mangan) asam sitrat, gliserol, lemak, lesitin, dan glyceryl phosphoryl choline (GPC) (Susilawati, 2011). AndroMed ${ }^{\circledR}$ juga mengandung lesitin nabati sebanyak $6,76 \mathrm{~g} / 100 \mathrm{ml}$ dan fruktosa yang berperan sebagai sumber energi sehingga spermatozoa dapat hidup dalam kondisi normal (Herdis et al., 2008).

Selain pengencer, waktu pre frezing juga berpengaruh terhadap kualitas semen beku. Pre freezing merupakan proses pembekuan semen dengan suhu tertentu sampai 
Prosiding Seminar Nasional Pembangunan dan Pendidikan Vokasi Pertanian

Politeknik Pembangunan Pertanian Manokwari, 31 Juli 2021

e ISSN : 2774-1982

DOI : https://doi.org/10.47687/snppvp.v2i1.183

mencapai suhu yang diinginkan. Pre freezing akan mempengaruhi kualitas semen yang dibekukan, seperti motilitas, persentase hidup, dan abnormalitas spermatozoa (Toelihere, 1985).

Lama waktu pre freezing menurut beberapa sumber berbeda. Straw yang telah berisi semen diletakkan pada permukaan nitrogen cair $4 \mathrm{~cm}$ dengan suhu berkisar $-110^{\circ} \mathrm{C}$ sampai $-120^{\circ} \mathrm{C}$ selama 9 menit (BIB Ungaran, 2011). Pembekuan berlangsung selama 9 menit (Nilna, 2010). Umar dan Maharani (2005) meyatakan bahwa pre freezing selama 9 menit memberikan angka persentase motilitas spermatozoa sebesar $47,25 \%$ pada sapi Limosin.

Semen beku dengan pre freezing selama 9 menit memberikan kualitas yang baik terhadap semen sapi Simmental yang menggunakan pengencer AndroMed ${ }^{\circledR}$, sehingga semen beku yang dihasilkan memenuhi syarat untuk dipergunakan dalam inseminasi buatan yaitu mempunyai persentase motilitas post thawing sebesar $40 \%$. Rata-rata persentase spermatozoa hidup tertinggi yaitu 50,74\% diperoleh pada perlakuan waktu pre freezing selama 9 menit dan terendah $17,15 \%$ diperoleh pada perlakuan waktu pre freezing selama 5 menit (Pratiwi et al., 2014)

Lama waktu pre freezing merupakan masalah penting dalam proses pembekuan semen untuk mempertahankan fertilitas spermatozoa, namun demikian di UPTD IB Bengkulu belum diketahui lama waktu pre freezing yang terbaik, sehingga perlu penelitian mengenai waktu pre freezing yang tepat. Hasil penelitian ini diharapkan dapat memberikan informasi lebih lanjut mengenai lama waktu pre freezing yang tepat untuk mempertahankan kualitas dari semen beku sapi Bali di UPTD IB Bengkulu.

Penelitian ini bertujuan untuk mengevaluasi pengaruh waktu pre freezing terhadap kualitas semen beku sapi Bali di UPTD IB Bengkulu. Dengan hipotesis bahwa penggunaan pengencer AndroMed ${ }^{\circledR}$ dengan waktu pre freezing yang tepat dapat mempertahankan motilitas, persentase hidup, dan meminimalisir abnormalitas spermatozoa.

\section{METODE}

\section{Waktu dan Tempat Penelitian}

Penelitian ini dilaksanakana pada bulan Desember 2020 sampai bulan Januari 2021 yang bertempat di UPTD IB Bengkulu. 
Prosiding Seminar Nasional Pembangunan dan Pendidikan Vokasi Pertanian

Politeknik Pembangunan Pertanian Manokwari, 31 Juli 2021

e ISSN : 2774-1982

DOI : https://doi.org/10.47687/snppvp.v2i1.183

\section{Alat dan Bahan}

Alat dan bahan yang akan digunakan adalah semen sapi Bali, eosin-nigrosin, AndroMed ${ }^{\circledR}$, aquabides, larutan $\mathrm{NaCl}$, object dan cover glass, mikroskop (Olympus), gelas ukur volume $100 \mathrm{ml}$, layar TV untuk melihat hasil dari mikroskop, tabung spermatozoa, termometer, $\mathrm{pH}$ meter, kertas label, automatic filling and sealing, photometer, container, cooltube, pinset, gunting, air, easy corder, tissue, waterbath, heating table, dan kotak stryofoam.

\section{Metode Penelitian}

Prosedur penelitian ini dimulai dengan menampung semen dari pejantan sapi Bali menggunakan vagina buatan. Selanjutnya dilakukan evaluasi kualitas semen meliputi pemeriksaan secara makroskopis (volume, warna, $\mathrm{pH}$, dan konsistensi) dan mikroskopis (konsentrasi dan motilitas spermatozoa). Semen segar yang memenuhi syarat diencerkan menggunakan AndroMed ${ }^{\circledR}$ dan aquabides dengan perbandingan 1:4 sesuai dari hasil penelitian Arnentis (2020). Selanjutnya dilakukan proses filling sealing secara otomatis ke dalam straw yang berisi $0,25 \mathrm{ml}$ semen. Setelah semen dikemas dalam bentuk straw, semen diekuilibrasi di dalam cool tube selama 4 - 6 jam dengan suhu $5^{\circ} \mathrm{C}$.

Langkah selanjutnya yaitu meletakkan straw di atas uap nitorgen cair menggunakan kotak stryrofoam yang sudah diisi nitrogen cair dengan batas ketinggian 7 $\mathrm{cm}$, sedangkan jarak permukaan nitrogen cair dengan straw di dalam boks $4 \mathrm{~cm}$. Sampel dibagi sesuai perlakuan waktu pre freezing yang diteliti (5, 7, 9, dan 11 menit) sebanyak 4 kali perlakuan dengan 18 kali pengulangan. Setelah itu, straw dimasukkan ke dalam goblet dan dibekukan ke dalam nitrogen cair selama 3 - 5 detik, lalu semen tersebut disimpan dalam kontainer dengan suhu $-196^{\circ} \mathrm{C}$. Selanjutnya dilakukan evaluasi post thawing dengan pengamatan motilitas, persentase hidup, dan abnormalitas spermatozoa. Pengambilan sampel straw dilakukan secara acak, data yang di peroleh dari hasil penelitian akan dianalisis menggunakan ANOVA (Analysis of Variance) dengan tingkat kepercaaan 5\%. Selanjutnya hasil yang berbeda nyata diuji lanjut dengan uji Duncan's Multiple Range Test (DMRT) dengan menggunakan aplikasi SPSS versi 24. 
Prosiding Seminar Nasional Pembangunan dan Pendidikan Vokasi Pertanian

Politeknik Pembangunan Pertanian Manokwari, 31 Juli 2021

e ISSN : 2774-1982

DOI : https://doi.org/10.47687/snppvp.v2i1.183

\section{HASIL DAN PEMBAHASAN}

\section{Evaluasi Kualitas Semen Segar}

Penampungan pada penelitian ini dilakukan sebanyak 2 kali ejakulasi untuk memperoleh semen segar. Kualitas semen segar dapat dilihat dari hasil pemeriksaan secara makroskopis dan mikroskopis seperti yang ada pada Tabel 1 .

Tabel 1. Hasil evaluasi kualitas semen segar

\begin{tabular}{lcc}
\hline Parameter & Rataan \pm SD & Kisaran \\
\hline Makroskopis & & \\
Volume (ml) & $5,8 \pm 0,1$ & $5,7-5,9$ \\
Warna & Putih Susu & Putih susu \\
pH & $6,5 \pm 0$ & 6,5 \\
Bau & Khas & Khas \\
Konsistensi & Sedang & Sedang - Kental \\
\hline Mikroskopis & & \\
Konsentrasi (Juta Sel Spermatozoa/ml) & $1160 \pm 252$ & $908-1413$ \\
Gerakan Massa & ++ & ++-+++ \\
Motilitas (\%) & $72,5 \pm 2,5$ & $70-75$ \\
\hline
\end{tabular}

Pemeriksaan secara makroskopis memperlihatkan bahwa volume semen segar yang diperoleh dari hasil penelitian berkisar antara 5,7 - 5,9 ml. Kisaran volume ini dapat dikatakan normal sesuai dengan Suteky et al. (2017) yang menyatakan bahwa volume semen segar sapi Bali di UPTD IB Bengkulu berkisar antara 5-5,4 ml. Volume rata-rata semen sapi 5 ml/ejakulasi (Direktorat Jenderal Peternakan, 2007). Menurut Toelihere (1993) volume semen sapi jantan berkisar 1 - 15 ml. Garner dan Hafez (2000) menyatakan bahwa volume semen sapi berkisar dari $5-8 \mathrm{ml} /$ ejakulasi.

Warna semen sapi Bali pada penelitian ini adalah putih susu. Menurut Direktorat Jenderal Peternakan (2007) warna semen sapi normal meliputi putih susu, krem dan kekuning-kuningan. Partodihardjo (1992) menyatakan bahwa semen sapi yang normal berwarna kream keputih-putihan atau hampir seputih susu. Derajat kekeruhannya atau keputih-putihannya berhubungan dengan konsentrasi spermatozoa, semakin keruh warna semen maka semakin banyak jumlah sperma yang terkandung dalam setiap ml semen. Sekitar 10\% sapi-sapi jantan menghasilkan semen yang normal berwarna kekuningkuningan yang disebabkan oleh pigmen riboflavin yang dibawakan oleh satu gen autosom resesif dan tidak mempunyai pengaruh terhadap fertilitas. Hasil pemeriksaan yang didapat menunjukkan bahwa warna semen segar dalam keadaan normal. 
Prosiding Seminar Nasional Pembangunan dan Pendidikan Vokasi Pertanian

Politeknik Pembangunan Pertanian Manokwari, 31 Juli 2021

e ISSN : 2774-1982

DOI : https://doi.org/10.47687/snppvp.v2i1.183

Derajat keasaman $(\mathrm{pH})$ semen segar sapi Bali pada penelitian ini adalah 6,5 dan termasuk ke dalam $\mathrm{pH}$ normal. Hasil ini tidak jauh berbeda dengan $\mathrm{pH}$ semen sapi Bali di Nusa Tenggara Timur (NTT) yaitu 7 (MataHine et al., 2014). Menurut Direktorat Jenderal Peternakan nomor 12207/hk.060/f/12/2007, pH semen segar yang digunakan sebagai semen beku berkisar antara 6,2-6,8. pH semen segar sapi adalah 6,4-7,8 (Toelihere, 1985).

Bau semen sapi Bali yang diperoleh pada penelitian adalah bau khas semen dan bisa dilakukan proses ke tahap selanjutnya karena semen tersebut termasuk dalam kategori semen normal dan tidak terdapat kontaminasi pada semen, sesuai dengan Rizal dan Herdis (2008) yang menyatakan bahwa pada umumnya bau semen dikategorikan sebagai bau khas. Menurut Direktorat Jenderal Peternakan (2007) bau semen segar adalah spesifik atau normal.

Konsistensi atau derajat kekentalan dari semen dapat diperiksa dengan menggetargetarkan tabung yang berisi semen secara perlahan-lahan. Semen segar yang didapatkan selama penelitian mempunyai konsistensi dengan kisaran sedang - kental dan termasuk dalam kategori normal. Hal ini sesuai dengan Partodihardjo (1992) yang menyatakan bahwa semen yang baik mempunyai derajat kekentalan hampir sama atau sedikit lebih kental dari susu dan semen yang jelek mempunyai kekentalan sama seperti air buah kelapa.

Hasil pemeriksaan secara mikroskopis menunjukkan bahwa semen sapi Bali dalam penelitian ini mempunyai kisaran konsentrasi $908 \times 10^{6}-1413 \times 10^{6}$ dan masih temasuk dalam kategori normal sesuai dengan Suteky et al. (2017) yang menyatakan bahwa konsentrasi semen sapi produksi UPTD IB Bengkulu berkisar antara 600 - 900 juta/ml. Konsentrasi spermatozoa/ml semen berkisar dari 800 - 2.000 juta sel/ml (Garner dan Hafez, 2000) dan konsentrasi semen sapi jantan sekitar 800 - 1200 x 106/ml (Sorenson, 1979). Umumnya konsentrasi spermatozoa sejalan dengan perkembangan seksual dan kedewasaan sapi pejantan, pengaruh kesehatan reproduksi dan besar testis, serta kualitas pakan yang diberikan (Djanuar, 1985).

Menurut Toelihere (1985), gerakan massa spermatozoa yang normal berkisar antara (++) dan (+++). Motilitas gerakan massa yang diperoleh pada penelitian ini sekitar $(++)-(+++)$ yang memperlihatkan adanya gelombang-gelombang besar, gelap, dan aktif bagaikan gumpalan awan hitam yang bergerak cepat berpindah-pindah tempat. Motilitas individu spermatozoa yang diamati setelah penampungan adalah $70 \%-75 \%$ ditandai dengan adanya pergerakan progresif spermatozoa. Hasil ini sesuai dengan Toelihere (1993) 
Prosiding Seminar Nasional Pembangunan dan Pendidikan Vokasi Pertanian

Politeknik Pembangunan Pertanian Manokwari, 31 Juli 2021

e ISSN : 2774-1982

DOI : https://doi.org/10.47687/snppvp.v2i1.183

yang menyatakan bahwa kebanyakan pejantan yang fertil mempunyai $50-80 \%$ spermatozoa yang motil aktif progresif dan yang dilaporkan Dewi et al. (2012) yang menemukan persentase motilitas spermatozoa sapi Bali di Indonesia adalah sebesar 74,50 $\pm 3,69 \%$.

Berdasarkan karakteristik yang dievaluasi secara makroskopis dan mikroskopis, dapat dinyatakan bahwa semen segar sapi Bali layak untuk digunakan proses lebih lanjut menjadi semen beku. Semen yang sudah memenuhi standar akan dibekukan, kemudian dievaluasi post thawing yang meliputi motilitas, persentase hidup, dan abnormalitas spermatozoa.

Pengaruh Waktu Pre Freezing terhadap Motilitas, Persentase Hidup, dan Abnormalitas Spermatozoa

Nilai pengamatan motilitas, persentase hidup, dan abnormalitas spermatozoa di lihat dari tujuh lapang pandang (minimal $200 \mathrm{sel}$ ). Motilitas atau daya gerak spermatozoa merupakan penilaian yang digunakan untuk menentukan kelayakan inseminasi buatan. Rata-rata motilitas spermatozoa dengan waktu pre freezing yang berbeda setelah thawing dapat dilihat pada Tabel 2.

Tabel 2. Pengaruh waktu pre freezing terhadap motilitas spermatozoa

\begin{tabular}{|c|c|c|c|c|c|c|c|}
\hline \multirow{2}{*}{ Perlakuan } & \multicolumn{6}{|c|}{ Ulangan } & \multirow{2}{*}{ Rata-rata \pm SD $(\%)$} \\
\hline & U1 & $\mathrm{U} 2$ & U3 & $\overline{\mathrm{U} 4}$ & $\overline{\mathrm{U} 5}$ & U6 & \\
\hline T1 & 58,33 & 60,00 & 51,67 & 41,67 & 41,67 & 40,00 & $48,89 \pm 8,98$ \\
\hline $\mathrm{T} 2$ & 50,00 & 56,67 & 45,00 & 45,00 & 41,67 & 43,33 & $46,95 \pm 5,52$ \\
\hline $\mathrm{T} 3$ & 46,67 & 43,33 & 46,67 & 56,67 & 43,33 & 46,67 & $47,22 \pm 4,91$ \\
\hline $\mathrm{T} 4$ & 48,33 & 53,33 & 48,33 & 58,33 & 48,33 & 51,67 & $51,39 \pm 4,00$ \\
\hline
\end{tabular}

Keterangan: $\mathrm{ns}=$ Menunjukkan perlakuan berbeda tidak nyata $(\mathrm{P}>0,05)$

$\mathrm{T} 1=$ Pre freezing selama 5 menit

$\mathrm{T} 2=$ Pre freezing selama 7 menit

T3 $=$ Pre freezing selama 9 menit

$\mathrm{T} 4=$ Pre freezing selama 11 menit

Hasil analisis ragam menunjukkan bahwa waktu pre freezing berpengaruh tidak nyata terhadap motilitas spermatozoa $(\mathrm{P}>0,05)$. Motilitas spermatozoa pada penelitian ini berkisar antara $45 \%$ - 50,83\% sehingga memenuhi syarat untuk digunakan dalam inseminasi buatan yaitu mempunyai persentase motilitas post thawing diatas $40 \%$. Menurut Garner dan Hafez (2000), syarat minimal motilitas individu sperma post thawing agar dapat dipergunakan dalam inseminasi buatan adalah $40 \%$. 
Prosiding Seminar Nasional Pembangunan dan Pendidikan Vokasi Pertanian

Politeknik Pembangunan Pertanian Manokwari, 31 Juli 2021

e ISSN : 2774-1982

DOI : https://doi.org/10.47687/snppvp.v2i1.183

Meskipun tidak berbeda nyata, waktu pre freezing pada perlakuan T4 (pre freezing selama 11 menit) memiliki angka motilitas yang tinggi bila dibandingkan dengan motilitas spermatozoa pada waktu pre freezing selama 5 - 9 menit. Hal ini disebabkan karena spermatozoa banyak mengalami kematian akibat masa adaptasi suhu yang lebih singkat. Kurangnya waktu adaptasi spermatozoa terhadap suhu dingin sebelum dimasukkan ke dalam nirogen cair $\left(-196^{\circ} \mathrm{C}\right)$ menyebabkan spermatozoa banyak mengalami kerusakan akibat cold shock dan perubahan-perubahan intraseluler yang berkaitan dengan pembentukan kristal-kristal es. Sementara itu, perlakuan T4 dengan waktu pre freezing selama 11 menit memberikan kesempatan yang lebih lama bagi spermatozoa untuk melakukan adaptasi terhadap penurunan suhu pada proses pre freezing sehingga dapat meminimalkan kerusakan-kerusakan tersebut.

Pengaruh perlakuan terhadap persentase hidup spermatozoa sapi Bali dapat dilihat pada Tabel 3. Pemeriksaan persentase spermatozoa hidup dilakukan menggunakan preparat ulas dengan pewarna eosin nigrosin, dengan batasan bahwa sperma hidup tidak dapat menyerap warna sedangkan spermatozoa mati menyerap warna karena permeabilitas dindingnya meningkat sehingga senyawa kimia dengan mudah akan masuk ke dalam sel.

Tabel 3. Pengaruh waktu pre freezing terhadap persentase hidup spermatozoa

\begin{tabular}{cccccccc}
\hline \multirow{2}{*}{ Perlakuan } & \multicolumn{7}{c}{ Ulangan } \\
\cline { 2 - 6 } & U1 & U2 & U3 & U4 & U5 & U6 & Rata-rata \pm SD (\%) \\
\hline T1 & 73,06 & 83,88 & 71,19 & 78,49 & 83,01 & 82,23 & $78,64 \pm 5,41$ \\
T2 & 68,39 & 92,28 & 72,77 & 89,08 & 75,68 & 81,86 & $80,01 \pm 9,41$ \\
T3 & 78,73 & 85,37 & 74,82 & 89,87 & 86,27 & 84,58 & $83,27 \pm 5,49$ \\
T4 & 76,82 & 83,33 & 78,64 & 82,25 & 81,21 & 85,21 & $81,24 \pm 3,08$ \\
\hline Probabilitas & \multicolumn{7}{c}{} \\
\hline
\end{tabular}

Keterangan: $\mathrm{ns}=$ Menunjukkan perlakuan berbeda tidak nyata $(\mathrm{P}>0,05)$

$\mathrm{T} 1=$ Pre freezing selama 5 menit

$\mathrm{T} 2=$ Pre freezing selama 7 menit

$\mathrm{T} 3=$ Pre freezing selama 9 menit

$\mathrm{T} 4=$ Pre freezing selama 11 menit

Hasil analisis ragam menunjukkan bahwa waktu pre freezing berpengaruh tidak nyata terhadap persentase hidup spermatozoa $(\mathrm{P}>0,05)$. Tidak adanya pengaruh yang nyata terhadap persentase hidup spermatozoa ini diduga karena interval waktu yang rendah antar perlakuan.

Persentase spermatozoa hidup pada penelitian ini berkisar antara 76,63 - 85,14\%. Hasil penelitian ini masih bisa digunakan dalam inseminasi buatan sesuai dengan Hafez 
Prosiding Seminar Nasional Pembangunan dan Pendidikan Vokasi Pertanian

Politeknik Pembangunan Pertanian Manokwari, 31 Juli 2021

e ISSN : 2774-1982

DOI : https://doi.org/10.47687/snppvp.v2i1.183

(2000) yang menyatakan bahwa persentase hidup semen sapi segar sebesar $60-80 \%$.

Semen yang baik memiliki persentase viabilitas diatas 50\% (Toelihere, 1993). Persentase hidup spermatozoa selalu lebih tinggi dibandingkan dengan motilitas spermatozoa (Bearden dan Fuquay, 2000).

Meskipun tidak berbeda nyata, waktu pre freezing selama 9 menit menunjukkan angka persentase hidup spermatozoa yang lebih tinggi daripada waktu pre freezing selama 5,7, dan 11 menit. Menurut Janur et al. (2015) faktor penyebab rendahnya persentase hidup spermatozoa setelah dilakukan thawing adalah akibat banyaknya asam laktat dari hasil metabolisme spermatozoa yang tidak dapat dioksidasi. Menumpuknya asam laktat ini mengakibatkan kadar keasaman larutan meningkat juga dan berakibat buruk bagi spermatozoa karena bersifat racun. Menurut Pangestu (2002), 50\% sperma mamalia akan mati setelah pembekuan dan thawing. Menurut Yudhaningsih (2004), suhu yang rendah dapat mengakibatkan substansi vital dalam spermatozoa bocor sehingga enzim intraseluler, lipoprotein, ATP, kalium intraseluler dan lemak berfosfor berkurang dan menyebabkan kerusakan membran plasma. Menurut Kusuma (1990), matinya sperma disebabkan cadangan makanan berkurang dan tidak seimbangnya elektrolit larutan akibat metabolisme sperma.

Pengaruh perlakuan terhadap abnormalitas spermatozoa sapi Bali dapat dilihat pada Tabel 4. Pemeriksaan persentase abnormalitas spermatozoa dilakukan menggunakan preparat ulas dengan pewarna eosin nigrosin, kemudian mengamati setiap spermatozoa yang mengalami abnormalitas.

Tabel 4. Pengaruh waktu pre freezing terhadap abnormalitas spermatozoa

\begin{tabular}{|c|c|c|c|c|c|c|c|}
\hline \multirow{2}{*}{ Perlakuan } & \multicolumn{6}{|c|}{ Ulangan } & \multirow{2}{*}{ Rata-rata \pm SD $(\%)$} \\
\hline & U1 & $\mathrm{U} 2$ & U3 & $\mathrm{U} 4$ & U5 & U6 & \\
\hline T1 & 14,44 & 8,75 & 10,52 & 10,31 & 8,05 & 6,84 & $9,82 \pm 2,65$ \\
\hline $\mathrm{T} 2$ & 14,96 & 10,89 & 11,20 & 8,58 & 8,98 & 12,30 & $11,15 \pm 2,33$ \\
\hline T3 & 11,41 & 8,83 & 10,95 & 8,99 & 6,93 & 7,96 & $9,18 \pm 1,72$ \\
\hline $\mathrm{T} 4$ & 16,14 & 8,61 & 11,44 & 9,98 & 8,13 & 5,74 & $10,01 \pm 3,56$ \\
\hline Probabilitas & & & & & & & 0,64 ns \\
\hline
\end{tabular}

Keterangan: $\mathrm{ns}=$ Menunjukkan perlakuan berbeda tidak nyata $(\mathrm{P}>0,05)$

$\mathrm{T} 1=$ Pre freezing selama 5 menit

$\mathrm{T} 2=$ Pre freezing selama 7 menit

$\mathrm{T} 3=$ Pre freezing selama 9 menit

$\mathrm{T} 4=$ Pre freezing selama 11 menit

Hasil analisis ragam, menunjukkan bahwa perlakuan waktu pre freezing berpengaruh tidak nyata terhadap abnormalitas spermatozoa setelah thawing $(\mathrm{P}>0,05)$. 
Prosiding Seminar Nasional Pembangunan dan Pendidikan Vokasi Pertanian

Politeknik Pembangunan Pertanian Manokwari, 31 Juli 2021

e ISSN : 2774-1982

DOI : https://doi.org/10.47687/snppvp.v2i1.183

Abnormalitas spermatozoa berkisar antara 9,25 - 12,10\%. Meskipun perlakuan tidak berpengaruh nyata, waktu pre freezing selama 9 menit menunjukkan angka abnormalitas yang lebih rendah dibandingkan dengan pre freezing selama 5, 7, dan 11 menit.

Waktu pre freezing untuk semua perlakuan tidak menyebabkan abnormal yang tinggi pada spermatozoa dan masih layak IB, karena abnormalitas yang diperoleh masih di bawah 20\%. Sesuai dengan Toelihere (1993) menyatakan bahwa spermatozoa yang tidak lebih dari 20\% masih dikatakan layak untuk digunakan pada inseminasi buatan. Semen masih layak untuk digunakan inseminasi buatan (IB) jika abnormalitas di bawah 20\% (SNI semen beku Nasional, 2017).

Abnormalitas spermatozoa digolongkan pada abnormalitas primer dan sekunder. Menurut Partodihardjo (1992) bentuk abnormalitas primer yang terjadi pada spermatozoa berasal dari gangguan pada testes atau mungkin karena memang cacat dan bentuk abnormalitas sekunder yang terjadi pada spermatozoa berasal dari kesalahan perlakuan setelah meninggalkan testes, diantaranya karena kocokan yang keras dalam tabung penampung, pengeringan yang terlalu cepat, pemanasan yang berlebihan, dan penggesekan yang tidak hati-hati. Rataan abnormalitas primer dan sekunder pada setiap perlakuan dapat dilihat pada Tabel 5.

Tabel 5. Pengaruh waktu pre freezing terhadap abnormalitas primer dan sekunder spermatozoa

\begin{tabular}{cccc}
\hline \multirow{2}{*}{ Perlakuan } & \multirow{2}{*}{ Abnormalitas (\%) } & \multicolumn{2}{c}{ Abnormalitas (\%) } \\
\cline { 3 - 4 } & & Primer & Sekunder \\
\hline T1 & 9,82 & 2,04 & 7,78 \\
T2 & 11,15 & 2,69 & 8,46 \\
T3 & 9,18 & 1,09 & $\mathbf{8 , 0 9}$ \\
T4 & 10,01 & 1,98 & $\mathbf{8 , 0 3}$ \\
\hline Rataan & $\mathbf{1 0 , 0 4}$ & 1,95 & $\mathbf{8 , 0 9}$ \\
\hline
\end{tabular}

Keterangan: $\mathrm{T} 1=$ Pre freezing selama 5 menit $\mathrm{T} 2=$ Pre freezing selama 7 menit T3 $=$ Pre freezing selama 9 menit $\mathrm{T} 4$ = Pre freezing selama 11 menit

Spermatozoa yang abnormal tidak akan mampu untuk membuahi ovum tanpa melihat kategori abnormalitas tersebut (Toelihere, 1993). Kelainan pada kepala seperti kepala kecil, besar, kerucut dan miring, memiliki ekor dua, akrosom yang salah bentuk, dan terdapat dua kepala termasuk kategori abnormalitas primer, sedangkan kelainan 
Prosiding Seminar Nasional Pembangunan dan Pendidikan Vokasi Pertanian

Politeknik Pembangunan Pertanian Manokwari, 31 Juli 2021

e ISSN : 2774-1982

DOI : https://doi.org/10.47687/snppvp.v2i1.183

dengan ciri kepala terpisah dari ekor, ekor yang kusut atau bergulung dan ekor patah termasuk kategori abnormalitas sekunder (Partodihardjo, 1992).

Berdasarkan Tabel 5, terlihat bahwa rataan abnormalitas dari semua perlakuan (5, 7, 9, dan 11 menit) sebesar 10,04\% dengan rataan abnormalitas primer sebesar 1,95\% dan rataan abnormalitas sekunder sebesar 8,09\%. Kelainan abnormalitas sekunder yang ditemukan pada penelitian ini kebanyakan adalah kepala terlepas, leher patah, ekor patah, dan ekor bergelung. Sedangkan kelainan abnormalitas primer yang ditemui pada penelitian ini kebanyakan adalah kelainan pada kepala dan memiliki ekor dua. Hal ini sesuai dengan Rizal dan Herdis (2008) yang menyatakan bahwa abnormalitas sekunder lebih banyak ditemukan dibandingkan abnormalitas primer.

\section{KESIMPULAN DAN SARAN}

\section{Kesimpulan}

Waktu pre freezing yang berbeda $(5,7,9$, dan 11 menit) tidak mempengaruhi motilitas, persentase hidup, dan abnormalitas spermatozoa.

\section{Saran}

Perlu dilakukan penelitian lebih lanjut mengenai fertilitas spermatozoa sapi Bali hasil pembekuan dengan variasi waktu pre freezing yang berbeda menggunakan pengencer AndroMed ${ }^{\circledR}$.

\section{DAFTAR PUSTAKA}

Arnentis. (2020). Pengaruh rasio penggunaan pengencer andromed ${ }^{\circledR}$ terhadap motilitas, persentase hidup dan abnormalitas semen sapi Bali di UPTD IB Bengkulu. Skripsi. Fakultas Pertanian Universitas Bengkulu, Bengkulu.

Bearden, H. J., \& J. W. Fuquay. (2000). Applied Animal Reproduction 5th Ed. Prentice Hall. Upper Saddle River, New Jersey.

BIB Ungaran. (2011). Standar Operasional Pelayanan (SOP). BIB Sidomulyo Ungaran, Semarang.

Dewi, A.S., Y.S Ondho \& E. Kurnianto. (2012). Kualitas semen berdasarkan umur pada sapi jantan Jawa. Animal Agriculture Journal. 1(2):126-133.

Direktorat Jenderal Peternakan. (2007). Petunjuk Teknis Produksi dan Distribusi Semen Beku. Nomor: 12207/HK.060/F/12/2007. Direktorat Jenderal Peternakan, Jakarta.

Djanuar, R. (1985). Fisiologi Reproduksi dan Inseminasi Buatan pada Sapi. Gadjah Mada University Press, Yogyakarta.

Feradis. (2010). Bioteknologi Reproduksi pada Ternak. Alfabeta, Bandung. 
Prosiding Seminar Nasional Pembangunan dan Pendidikan Vokasi Pertanian

Politeknik Pembangunan Pertanian Manokwari, 31 Juli 2021

e ISSN : 2774-1982

DOI : https://doi.org/10.47687/snppvp.v2i1.183

Garner, D. L. \& E. S. E. Hafez. (2000). Spermatozoa and Seminal Plasma. In Reproduction In Farm Animals. Edited by E. S. E. Hafez. 7th Edition. Lippincott Wiliams and Wilkins. Maryland, USA.

Herdis., M. Surachman, Yulnawati, M. Rizal, \& H. Maheshwari. (2008). Viabilitas dan keutuhan membran plasma spermatozoa epididimis kerbau Belang pada penambahan maltosa dalam pengencer Andromed ${ }^{\circledR}$. Journal of Indonesian Tropical Animal Agriculture. 33(2):101-106.

Janur G. H., M. N. Ihsan \& N. Isnaini. (2015). Pengaruh Berbagai Metode Thawing Terhadap Kualitas Semen Beku Kambing Peranakan Etawa (PE). Laporan Penelitian Fakultas Peternakan Universitas Brawijaya, Malang.

Kusuma, D. L. (1990). Pengaruh Berbagai Pengencer Susu dan Lahan Penyimpanan Terhadap Daya Hidup Sperma Domba (Oris Aries). Skripsi. Fakultas Pertanian. Universitas Sumatera Utara, Medan.

MataHine, T., Burhanuddin, \& A. Marawali. (2014). Efektivitas air buah lontar dalam mempertahankan motilitas, viabilitas dan daya tahan hidup spermatozoa sapi Bali. Jurnal Veteriner. 15(2):263-273.

Nilna. (2010). Standar Operasional Pekerjaan Prosesing Semen. Pengawas Mutu Bibit Ternak pada Dinas peternakan, Sumatera Barat.

Pangestu, M. (2002). Preservation of spermatozoa: methods and applications. Indonesian Forum on Reproduction. Journal on Reproduction. 1(2): 55 - 56.

Partodihardjo. (1992). Ilmu Reproduksi Hewan. Penerbit Mutiara Sumber Widya, Jakarta.

Pratiwi, I. R, S. Suharyati, \& M. Hartono. (2014). Analisis Kualitas Semen Beku Sapi Simmental Menggunakan Pengencer Andromed dengan Variasi Waktu Pre Freezing. Jurnal Ilmiah Peternakan Terpadu. 2 (3): 9 -13.

Rizal, M. \& Herdis. (2008). Inseminasi Buatan pada Domba. Rineka Cipta, Jakarta.

SNI. (2017). Semen Beku - Bagian 1: Sapi. BSN. 4869-1:2017.

Sorenson Jr., A.M. (1979). Laboratory Manual for Animal Reproduction. 4 Ed. American Press. Boston, USA.

Susiliwati, T. (2011). Spermatologi. Universitas Brawijaya Press, Malang.

Suteky, T., Sutriyono, Dwatmadji \& M.I. Solihin. (2017). Kualitas semen produksi UPTD Bengkulu dan tingkat keberhasilan inseminasi pada sapi Bali dan peranakan Simental di Bengkulu. Jurnal Sain Peternakan Indonesia. 12(2): 221-229.

Toelihere, M. R. (1981). Inseminasi Buatan pada Ternak. Penerbit Angkasa, Bandung.

Toelihere, M. R. (1993). Inseminasi Buatan pada Ternak. Penerbit Angkasa, Bandung.

Umar, S. \& M. Maharani. (2005). Pengaruh Berbagai Waktu Ekuilibrasi Terhadap Daya Tahan Sperma Sapi Limousin dan Uji Kebuntingan. Jurnal Agribisnis Peternakan. 1(1): 17-21. 